\title{
Waste management of used personal protective equipment during the COVID-19 pandemic in the Eastern Mediterranean Region
}

\author{
Rola Al-Emam ${ }^{1}$ and Basel Al-Yousfi ${ }^{1}$
}

${ }^{1}$ World Health Organization Regional Office for the Eastern Mediterranean, Regional Centre for Environmental Health Action, Amman, Jordan. (Correspondence to: Basel Al-Yousfi: alyousfia@who.int)

Citation: Al-Emam R; Al-Yousfi B. Waste management of used personal protective equipment during the COVID-19 pandemic in the Eastern Mediterranean Region. East Mediterr Health J. 2021;27(11):1034-1035. https://doi.org/10.26719/2021.27.11.1034

Received: 23/02/21; accepted: 06/10/21

Copyright (C) World Health Organization (WHO) 2021. Open Access. Some rights reserved. This work is available under the CC BY-NC-SA 3.o IGO license (https://creativecommons.org/licenses/by-nc-sa/3.o/igo).

The COVID-19 pandemic continues to take a heavy toll on various sectors globally, including in the Eastern Mediterranean Region. While the world witnessed positive (but perhaps short-lived) environmental impacts from lockdowns and curtailed human activities, such as improved air and water quality and reduced greenhouse gas emissions, the impact of COVID-19 waste management has been less positive $(1,2)$, in particular the improper disposal of personal protective equipment (PPE) such as used face masks, coveralls, gowns and gloves. Waste management is an essential infection prevention and control activity and public health service that cannot be disregarded during these difficult times. Concerted efforts are needed to protect human health and the environment during and after the pandemic.

Wearing face masks is recommended by the World Health Organization (WHO) and other national disease control centres as part of the nonpharmaceutical interventions to control the spread of COVID-19. The continued use of masks by health workers and the public, indoors (such as in supermarkets or shopping malls), in public transport facilities and outdoors in crowded places, results in millions of items of PPE being manufactured and used daily. In Jordan, an estimated 1.1 million masks and 2.2 million gloves are used and disposed of on average every day (3). In the Islamic Republic of Iran, a study found that 5.6 million masks and more than 11 million gloves were discarded daily on average over a 3-month period (4).

Poverty, negligence, limited supply and high demand for masks may increase the likelihood of people collecting used face masks and reselling them (5). The improper disposal of used masks and gloves poses a major health threat and undermines national efforts to control the spread of infection in communities. Moreover, masks and other items of PPE may clog sewers and waterways, resulting in negative human health effects and broader environmental impacts (9). WHO has warned against disadvantages that may result from the increased use and improper handling and disposal of masks by the public such as random mask disposal leading to increased litter in public places, risk of contamination for street cleaners and environmental hazards (6). Several media articles in the Region have raised the issue of abandoned used face masks and gloves outside shopping malls, supermarkets and mosques, and along beaches $(7,8)$. Recognizing that so far there is limited evidence on transmission through fomites, such improperly discarded masks and gloves, which may be contaminated not only with the COVID-19 virus (SARS-CoV-2) but with other pathogens, can be blown around by the wind and lead to the dispersion of pathogens. Waste handlers and street sweepers are at especially high occupational health risk since they are in direct contact with such waste, but all outdoor workers (construction workers, policemen, etc.) and pedestrians are at risk of exposure to infection from improperly discarded masks and gloves.

The increased numbers of discarded PPE items exceed the capacity of the already limited and compromised waste management services observed in many developing countries, including those in the Eastern Mediterranean Region. In such countries, solid waste may be dumped in poorly designed and managed landfills or openly burned (with the latter leading to the release of harmful pollutants as dioxins and furans). A World Bank report states that $53 \%$ of solid waste in the Middle East and North Africa is disposed of in open dumps (9), putting waste handlers and pickers scavenging for recyclable items and neighbouring communities at major health risk in addition to nuisance. Waste collection, which is curtailed during lockdowns, is a critical step in managing waste. However, waste collection rates significantly vary by country income levels, with upper middle- and high-income countries providing nearly universal waste collection.

WHO has published several interim guidance notes on the safe management of COVID-19 waste. Waste generated from caring for COVID-19 patients at home as well as used PPE in the community should be disposed of in strong bags which are closed completely before collection by municipal waste services. Additionally, general noninfectious waste in health care facilities should be properly segregated from infectious waste such as sharps, bandages, pathological waste, and treated appropriately prior to safe disposal. 
WHO interim guidance lists preferred environmentally friendly treatment options as high temperature, dual-chamber incineration or autoclaving. If such services are unavailable, safe burying or controlled burning are interim measures until more sustainable and environmentally friendly procedures can be arranged. To prevent scavenging and reselling of used masks, efforts are needed to ensure safe waste disposal in fenced and regulated waste areas (9). The WHO Regional Centre for Environmental Health Action in the Eastern Mediterranean Region has been providing capacitybuilding and technical support to Member States for the safe integrated management of waste, including COVID-19 waste, and the occupational safety and health of waste handlers.

Safe management of COVID-19 waste requires proper classification and urgent action at all levels of society. Enforcement of regulations, provision of adequate safe waste management services and individual responsibility are all needed to control the improper disposal of used PPE. Unless waste (including PPE and infectious waste) is handled with due care, we risk the creation of new epicentres of diseases within our health care facilities and across society at large.

Health care waste management related to COVID-19 vaccination campaigns requires even closer attention. Large volumes of immunization waste including syringes, vials and PPE will be generated. To minimize waste from vaccination, use of PPE must be rational based on risk assessment as part of standard precautions. PPE additional to masks, for example gloves, is not indicated if skin is intact.

Countries should ensure that a safe and effective waste management plan, including training of health workers and provision of bins and treatment technologies, is in place prior to vaccine deployment (10). Unless safe waste management protocols and practices are established and monitored, such waste will pose a risk to health workers, the public and the environment. Perhaps the current pandemic will focus the attention of policyand decision-makers on the dire need to invest in safe waste management practices, ensure green recovery and build back better towards achieving the United Nations Sustainable Development Goals.

\section{References}

1. Saadat, S., Rawtani, D., Hussain, C.M. Environmental perspective of COVID-19. Sci. Total Environ. 2020;728(8), 138870. https:// doi.org/10.1016/j.scitotenv.2020.138870.

2. Zambrano-Monserrate, M.A., Ruano, M.A., Sanchez-Alcalde, L. Indirect effects of COVID-19 on the environment. Sci. Total Environ. 2020;728, 138813. https://doi.org/10.1016/j.scitotenv.2020.138813.

3. Royal Scientific Society (2020). Technical Opinion on Masks and Gloves Disposal Management during COVID-19. Retrieved from: https://www.rss.jo/news/technical-opinion-on-masks-and-gloves-disposal-management-during-covid-19/

4. Zand A.D., Heir A.V. Emerging challenges in urban waste management in Tehran, Iran during the COVID-19 pandemic. ResourcD es, Conservation and Recycling. 2020; 162(11). https://doi.org/10.1016/j.resconrec.2020.105051

5. WHO. Water, sanitation, hygiene, and waste management for SARS-CoV-2, the virus that causes COVID-19: Interim guidance. https://www.who.int/publications/i/item/water-sanitation-hygiene-and-waste-management-for-the-covid-19-virus-interim-guidance

6. WHO. Advice on the use of masks in the context of COVID-19: Interim guidance. https://www.who.int/publications/i/item/ advice-on-the-use-of-masks-in-the-community-during-home-care-and-in-healthcare-settings-in-the-context-of-the-novel-coronavirus-(2019-ncov)-outbreak

7. Ayyasrah, R (2020, August 26). Throwing masks and gloves on the streets is a health and environmental threat to citizens. Addustour. Retrieved from https://www.addustour.com/articles/1168434

8. Abed, A and Bayoumi, A (2020, May 19). Throwing masks and gloves in the streets is a source of spreading "Corona" ... and calls for tougher punishment for violators. Emaratalyoum. Retrieved from https://www.emaratalyoum.com/local-section/otha er/2020-05-19-1.1351311

9. Kaza, Silpa; Yao, Lisa C.; Bhada-Tata, Perinaz; Van Woerden, Frank (2018). What a Waste 2.0 : A Global Snapshot of Solid Waste Management to 2050. Urban Development;. Washington, DC: World Bank. @ World Bank. https://openknowledge.worldbank. org/handle/10986/30317

10. WHO. COVID-19 vaccination: supply and logistics guidance: Interim guidance. https://www.who.int/publications/i/item/who2019-ncov-vaccine-deployment-logistics-2021-1 